\title{
THE IMPACT OF CREMATED BONE DATING ON THE ARCHAEOLOGICAL CHRONOLOGY OF THE LOW COUNTRIES
}

\author{
Guy De Mulder ${ }^{1,2} \cdot$ Mark Van Strydonck $^{3} \cdot$ Mathieu Boudin $^{3}$
}

ABSTRACT. Since the publication of the first article (Lanting and van der Plicht 2001/2002) about the possibilities of dating cremated bones, the number of dated cremation remains has grown exponentially. The success of this dating technique lies in the fact that an absolute date now can be attributed to archaeological phenomena that previously were only datable indirectly. When archaeological artifacts where present, the cremation burials were dated based on the typology of ceramics and metals. An absolute date could be attributed if charcoal from the pyre were present. Unfortunately, these items were not omnipresent at the burial sites. Consequently, a complete site was dated by means of the few datable burials present. This implies that the internal chronology of the site could not be studied. Furthermore, the typochronology of the ceramics and the metals remains questionable. A series of dating projects on urnfield cemeteries in the Low Countries (northern France, Belgium, and the Netherlands) have shown that the classical chronology of these sites must be revised.

\section{INTRODUCTION}

In 1998, an article was published about the possibilities of using cremated bone for radiocarbon dating, and the first results of this project were promising (Lanting and Brindley 1998). This method uses structural carbonate, the so-called bioapatite, which survived the cremation process and was available for dating the remnants of the deceased (Lanting et al. 2001). The validity of this method has been tested in several ways. An intercomparison project on incinerated bone from different periods in the Netherlands and Flanders has been carried out (Naysmith et al. 2007). The quality of the incinerated bone necessary to have a reliable date and the chemical mechanism/process behind it has also been studied (Van Strydonck et al. 2005, 2009; Olsen et al. 2008).

The success of this dating technique lies in the fact that an absolute date can now be attributed to archaeological phenomena that previously were only datable indirectly. When archaeological artifacts were present, the cremation burials were dated based on the typology of ceramics and metals. An absolute date could be attributed if charcoal from the pyre were present. Charcoal, however, can have an important inbuilt age, resulting in an age difference between the ${ }^{14} \mathrm{C}$ date and the real cremation date. Furthermore, charcoal was not always omnipresent at the burial sites due to secondary funerary rites. Sometimes, only the cremated bones from the deceased were selected from the pyre for the deposition in a grave pit; thus, complete sites were dated by means of the few datable burials. This implies that the internal chronology of the site could not always be studied. Furthermore, the typochronology of the ceramics and the metals remains questionable. In the study region, the typochronological framework was based on comparative studies with central European funeral contexts, which were richer in metalwork and funerary pottery. In northwestern Europe, not all cremated bones were buried in an urn. Other ways of deposition in a perishable container or in a pit existed, which were difficult to date. Funerary gifts are not always omnipresent and consist mostly of a small cup or beaker. Metalwork is exceptional. Depending on the period, metalwork is found in wet contexts or in the funeral sphere (De Mulder et al. 2007). Rich graves become more frequent during the Early Iron Age due to changes in the depositional rites and social representation.

\footnotetext{
${ }^{1}$ Department of Archaeology, Ghent University, Blandijnberg 2, 9000 Ghent, Belgium.

${ }^{2}$ Corresponding author. Email: Guy.DeMulder@UGent.be.

${ }^{3}$ Royal Institute for Cultural Heritage, Jubelpark 1, 1000 Brussels, Belgium.
} 
During the Bronze Age and Iron Age, cremation becomes a dominant feature of the funeral process in northwestern Europe depending on the region and the specific time period. In addition to the classical deposition of the cremated remains in an urn, 3 different types of unurned deposition exist in the studied region. In 1 type, the bones from the pyre are wrapped in a perishable container like a piece of cloth, leather, or a wooden basket (the so-called "bonepackgrave" or Knochenlager in German). There is a variant of this type in which the bones are concentrated in a supposed perishable container in the pit and covered by remnants from the pyre. This is known as the Destelbergen type. Finally, there is the typical so-called Brandgrubengrab in which cremated bones and remains of the pyre are mixed and put together in a pit without any distinction. In this type of deposition, sometimes only a limited set of the cremated remains is deposited in the grave (De Laet et al. 1986; De Mulder 1994).

In the present paper, a series of dating projects on urnfield cemeteries from the Late Bronze Age and Early Iron Age in northern France, Belgium, and the Netherlands are presented together. In a first step, the recent results from 2 Belgian sites will be presented and discussed at the micro-level of the cemetery. Next, the ${ }^{14} \mathrm{C}$ results from these 2 sites and other cemeteries in northwestern Europe will be compared and confronted with the traditional archaeological ideas and concepts of the Late Bronze Age and Early Iron Age urnfields of the studied region.

Although this paper focuses on the Late Bronze Age and Early Iron Age in northern France, Belgium, and the Netherlands, other important projects on cremated bones have been undertaken. The Irish Early Bronze Age has been defined by dating the cremated remains and testing the typochronology of the typical decorated urn types, the so-called food vessels and urns, found in the graves of this period on the island (Brindley 2007). A similar dating project was initiated in Scotland where the different types of Bronze Age funeral urns and their preserved cremated bones are the research subject (Sheridan 2003). The ${ }^{14} \mathrm{C}$ laboratory at Groningen has not only delivered an important series of ${ }^{14} \mathrm{C}$ dates for the Late Bronze Age and Early Iron Age (Lanting and van der Plicht 2001/2002), but cremations of several cemeteries of the Middle and Late Iron Age in the Netherlands were also subjected to some kind of testing (Lanting and van der Plicht 2005/2006).

\section{CULTURAL AND CHRONOLOGICAL FRAMEWORK}

The study area, covering northern France, Belgium, and the southern Netherlands, belonged to the "Atlantic region" during the Bronze Age. During the Early and Middle Bronze Age, the tradition of erecting round barrows was a typical feature of the burial tradition in this region. From 1300 BC onwards, the group Rhin-Suisse-France orientale (RSFO) developed in the central European region of southern Germany, Switzerland, and eastern France. This RSFO group was part of an important economical and demographical expansion between 1300-1100 BC (phase 1). From 1100 BC, its influence spreads west, incorporating central France and southern Belgium in its territory (Figure 1). The regions at its borders are culturally influenced by the RSFO group. This is visible in the appearance of pottery shapes and decoration styles, imitating examples from the RSFO group, in western Belgium and northwestern France at the Atlantic coast. Bronze objects with a continental origin also become frequent in the Late Bronze Age deposits from Atlantic Europe. This second phase covers traditionally the period from 1100-900 BC (Brun 1984, 1988). This period was also characterized by the spread of the urnfield cemetery tradition over the study region. Cremation and the deposition of human remains in flat graves became a dominant feature in most of western Europe. The urnfield cemeteries were constructed on sites away from the traditional barrow sites. The tradition of erecting barrows disappeared, although in some regions they did survive. In the "northwestern" group (which spans the southern Netherlands, eastern Belgium, and a part of western Germany), funeral 


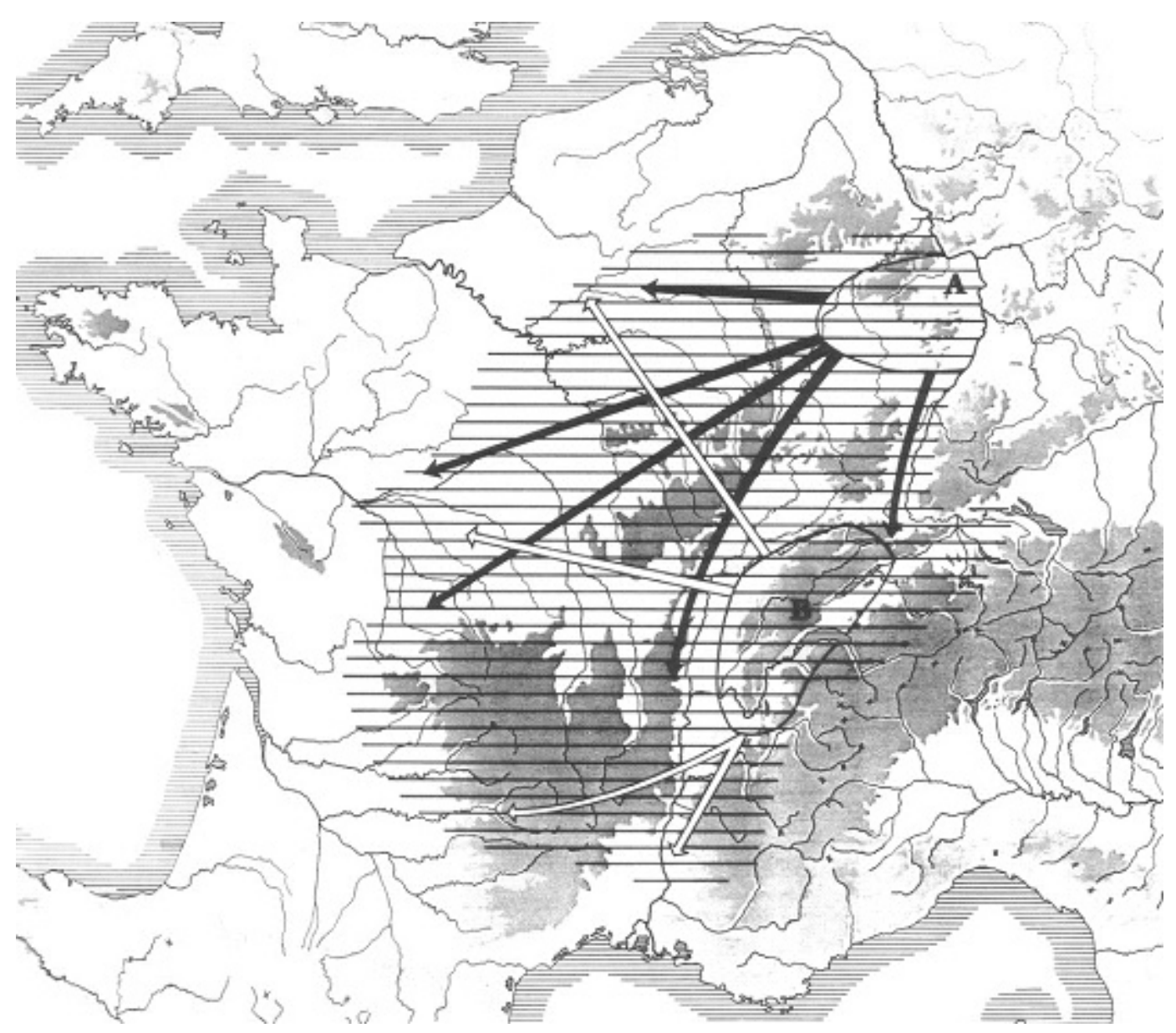

Figure 1 Expansion of the group Rhin-Suisse-France orientale (RSFO) during phase 2 of the Late Bronze Age (after Brun 1988). The areas A and B represent the core areas from which the group RSFO ceramics spread over northwestern Europe.

monuments are still frequently observed in the cemeteries of this period. The barrows are smaller in comparison with their Early and Middle Bronze Age predecessors (Desittere 1968).

After $900 \mathrm{BC}$, the dominant cultural influence of the RSFO group disappeared due to an internal socio-economic crisis (Brun 1988). Depending on the region, changes to the funeral ritual and the social structure become evident. New cemeteries appear while some urnfield graveyards stay in use until the Early Iron Age. The first results from the dating of cremated bone have resulted in a proposal to slightly modify the chronology of the Late Bronze Age and Early Iron Age in central and northern Europe (Table 1) (Lanting and van der Plicht 2001/2002).

\section{SITE DESCRIPTION}

In this paper, the recent dating results from 2 urnfield cemeteries in different areas of Belgium will be presented (Figure 2). Both sites are located on sandy soils. This information will be further discussed in the light of other obtained ${ }^{14} \mathrm{C}$ dates in the study area. 
Table 1 Chronological sequence of the Late Bronze Age and Early Iron Age in western Europe according to the chronological framework proposed at the congress of Nemours (Kimmig 1988) and the new proposition by Lanting and van der Plicht (2001/2002) based on absolute dates in southern Germany and neighboring areas.

\begin{tabular}{llcl}
\hline Chronology & Period & Kimmig/Brun & Lanting and van der Plicht \\
\hline Middle Bronze Age & Bronzezeit C & -1300 & $1475-1325$ \\
Late Bronze Age & Bronzezeit D (Bz D) & $1300-1200$ & $1325-1200$ \\
& Hallstatt A1 (Ha A1) & $1200-1100$ & $1200-1125$ \\
& Hallstatt A2 (Ha A2) & $1100-1000$ & $1125-1025$ \\
& Hallstatt B1 (Ha B1) & $1000-900$ & $1025-925$ \\
& Hallstatt B2 (Ha B2) & $900-800$ & - \\
Early Iron Age & Hallstatt B3 (Ha B3) & & $925-800$ \\
& Hallstatt C (Ha C) & $800-600$ & $800-625$ \\
Late Iron Age & Hallstatt D (Ha D) & $600-475$ & $625-480$ \\
\hline
\end{tabular}

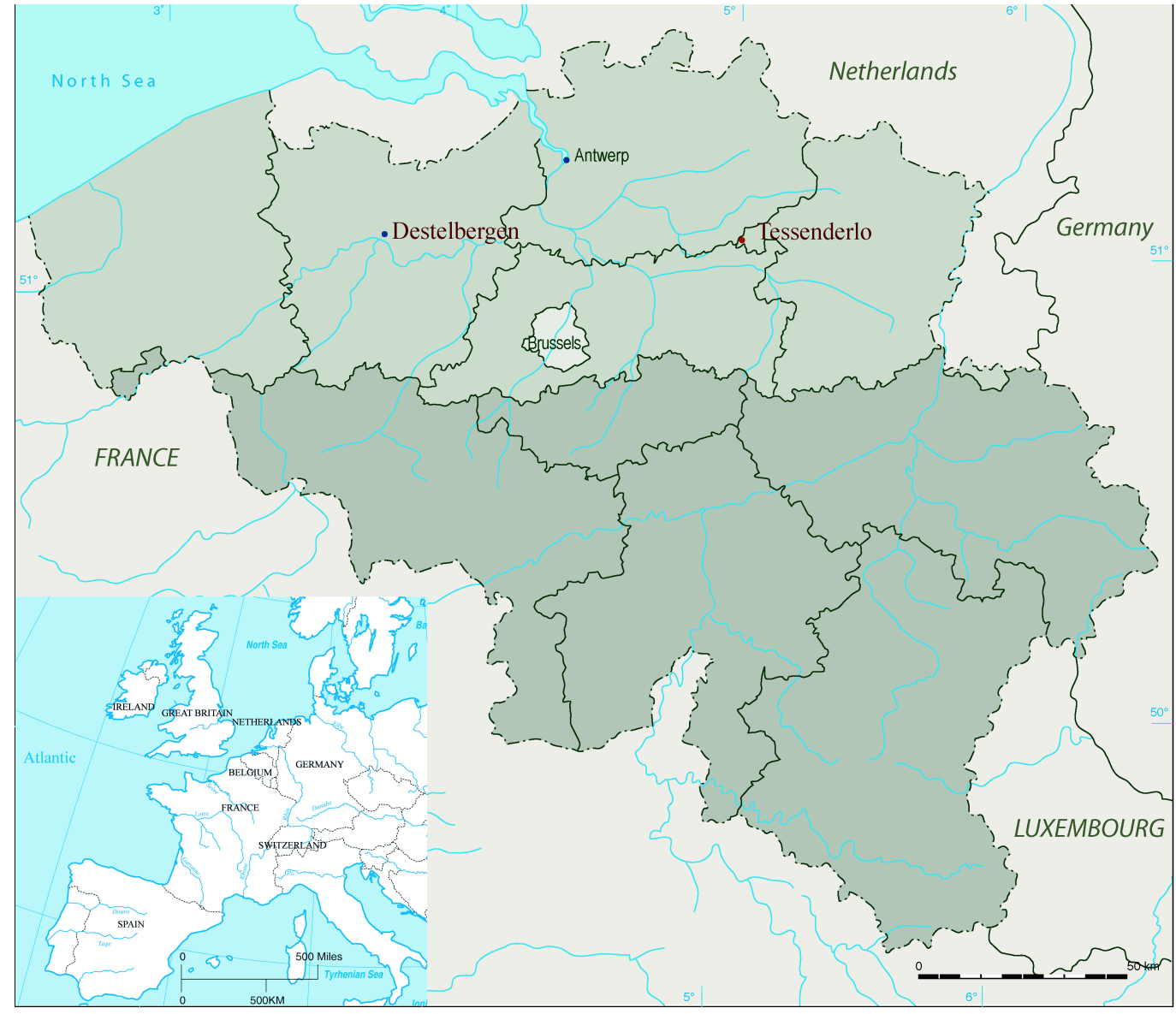

Figure 2 Location of the sites of Destelbergen (East Flanders) and Tessenderlo (Limbourg) 


\section{Destelbergen}

The urnfield cemetery of Destelbergen, located near Ghent in western Belgium, was discovered by a local amateur archaeologist in 1927-1928 during sand digging. In 1960, the first excavation was undertaken by Prof De Laet of Ghent University, and work continued on the site until 1984. During this period, 106 graves of an urnfield graveyard were uncovered together with a series of funeral monuments (Figure 3). Based on a typochronological study of the finds, a horizontal stratigraphy was recognized. The oldest monument was a round barrow in the center of the cemetery, supposed to date to the Ha A2 period. To the east of this barrow the Late Bronze Age area of the urnfield was located, in which some oval funerary structures were uncovered. The area to the west of the barrow was in use during the Early Iron Age. In this zone, 6 quadrangular monuments were excavated (De Laet et al. 1986).

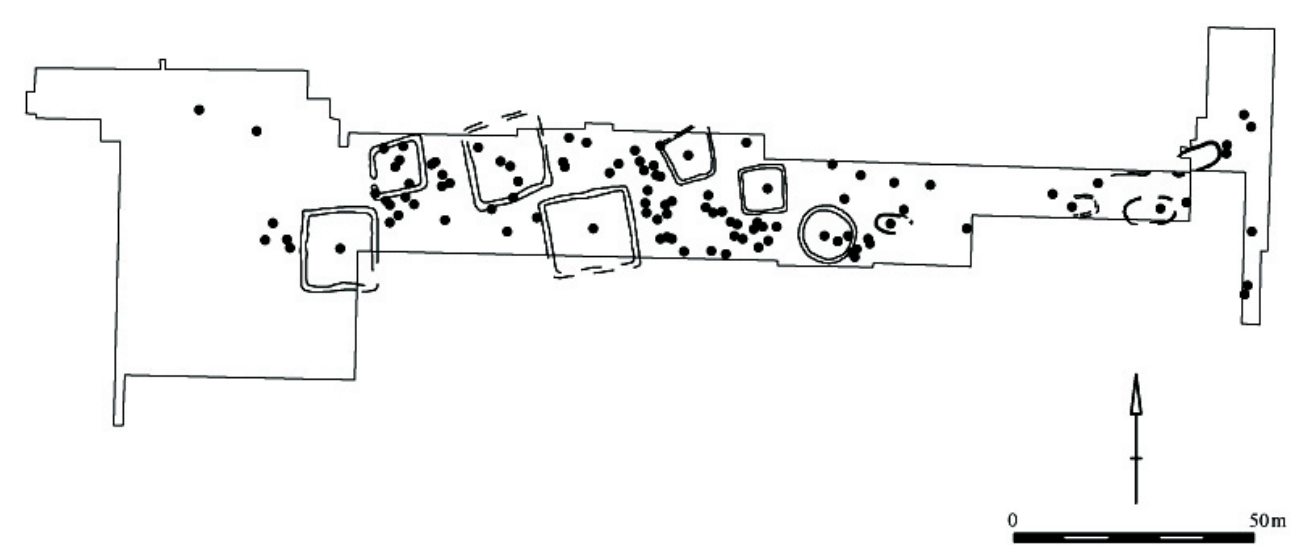

Figure 3 Linear organization of the urnfield at Destelbergen from east to west following the sandy ridge (De Laet et al. 1986).

\section{Tessenderlo}

Tessenderlo is situated in the eastern part of Belgium. The urnfield cemetery was excavated from 1993 until 1995 in a series of preventive archaeological actions, coordinated by the former Instituut voor het Archeologisch Patrimonium of the Flemish government and the province of Limbourg (Figure 4). It has not been completely uncovered for the moment. Some 49 cremation graves were discovered together with a circular structure and a rectilinear funerary structure (a langebed). A preliminary study of the finds placed the occupation period of the site in the Early Iron Age (Creemers 1994, 1997).

\section{MATERIALS AND METHODS}

${ }^{14} \mathrm{C}$ dates for both sites were obtained from cremated bone (CB) and charcoal (CC). CC samples were pretreated using the AAA method. CB samples followed the procedure described in De Mulder et al. (2007) and Van Strydonck et al. (2009). Targets were prepared at the Royal Institute for Cultural Heritage in Brussels (Belgium) (Van Strydonck and van der Borg 1990/1991) and measured at the Leibniz Labor für Altersbestimmung und Isotopenforschung in Kiel (Germany) (Nadeau et al. 1998).

\section{Destelbergen}

There are $22{ }^{14} \mathrm{C}$ dates available for the site of Destelbergen: 6 on CC and 16 on CB (Table 2). Two graves (18 and 75) have been double dated on CC and on CB. Both dates from grave 75 match sta- 

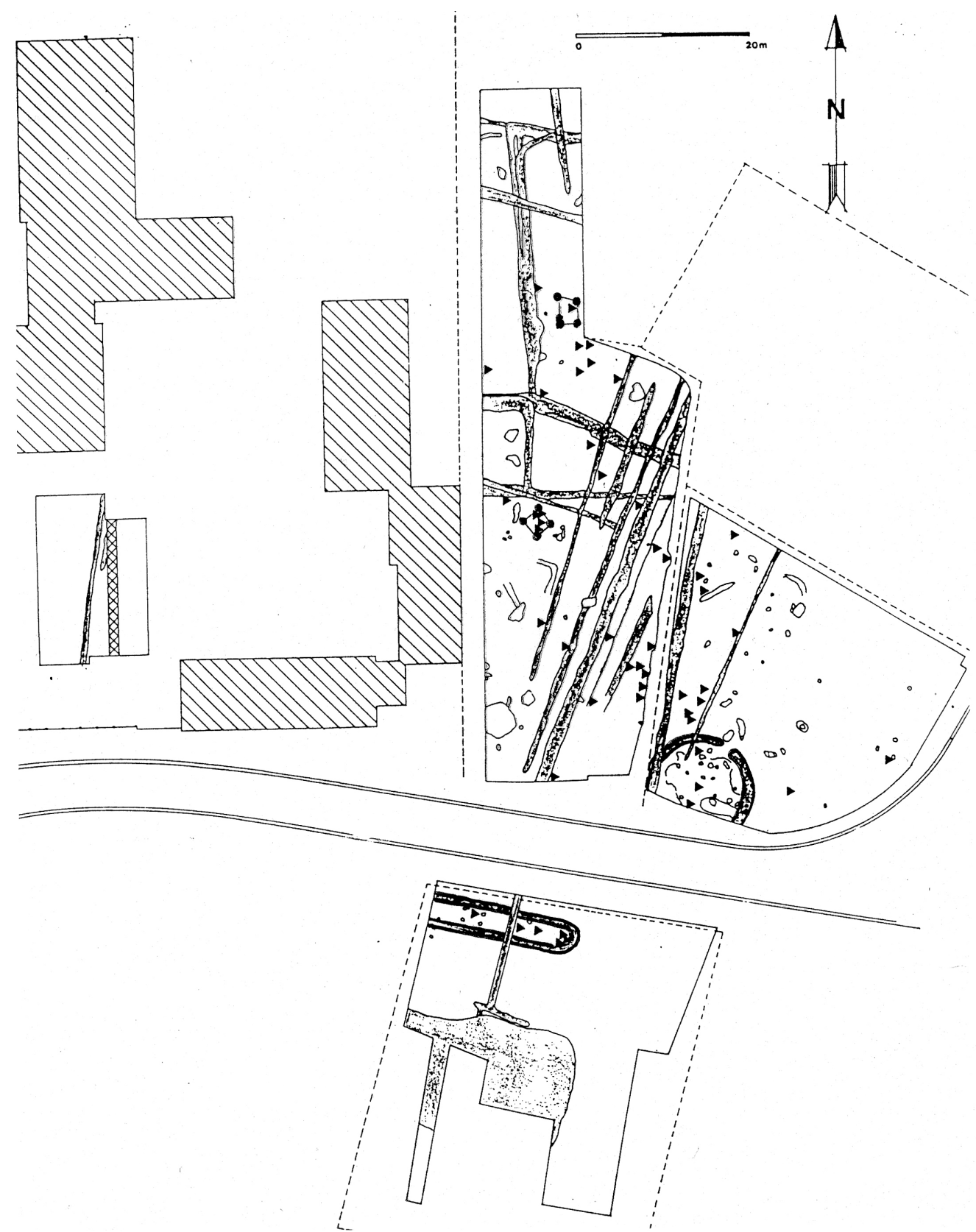

Figure 4 Excavation plan of the urnfield at Tessenderlo. The triangles $(\mathbf{\Delta})$ represent the cremation graves (after Creemers 1994, 1997). Both funerary monuments are located in the southern part of the cemetery.

tistically and can be combined according the $\chi^{2}$ test $(d f=1, T=2.7$ (5\% 3.8) (R_Combine grave 75: $760-410 \mathrm{cal} \mathrm{BC})$. The age difference between the cremated bone and charcoal samples from grave 18 is too large. This difference can probably be ascribed to the old-wood effect of the CC. 
Table $2{ }^{14} \mathrm{C}$ dates from the urnfield cemetery at Destelbergen.

\begin{tabular}{|c|c|c|c|}
\hline \# grave & Materiala $^{\mathrm{a}}$ & Lab ID and date BP & Calibrated date $(2 \sigma)$ \\
\hline 4 & $\mathrm{CB}$ & KIA-34909: $2120 \pm 30$ & $\begin{array}{l}350(4.7 \%) 320 \mathrm{BC} \\
210(90.7 \%) 40 \mathrm{BC}\end{array}$ \\
\hline 9 & $\mathrm{CB}$ & KIA-34178: $2360 \pm 30$ & $530(95.4 \%) 380 \mathrm{BC}$ \\
\hline 10 & $\mathrm{CB}$ & KIA-34923: $2755 \pm 30$ & $980(95.4 \%) 820 \mathrm{BC}$ \\
\hline 12 & $\mathrm{CB}$ & KIA-34892: $2495 \pm 30$ & $790(95.4 \%) 510 \mathrm{BC}$ \\
\hline 18 & $\mathrm{CC}$ & KIA-35797: $2440 \pm 30$ & $\begin{array}{l}760(22.2 \%) 680 \mathrm{BC} \\
670(8.7 \%) 610 \mathrm{BC}\end{array}$ \\
\hline 18 & $\mathrm{CB}$ & KIA-34910: $2330 \pm 35$ & $\begin{array}{l}600(64.5 \%) 400 \mathrm{BC} \\
520(90.3 \%) 350 \mathrm{BC} \\
290(5.1 \%) 230 \mathrm{BC}\end{array}$ \\
\hline 26 & $\mathrm{CB}$ & KIA-35363: $2590 \pm 30$ & $\begin{array}{l}820(87.5 \%) 750 \mathrm{BC} \\
690(6.3 \%) 660 \mathrm{BC} \\
620(1.6 \%) 590 \mathrm{BC}\end{array}$ \\
\hline 32 & $\mathrm{CB}$ & KIA-35353: $2370 \pm 30$ & $540(95.4 \%) 380 \mathrm{BC}$ \\
\hline 33 & $\mathrm{CC}$ & KIA-34154: $2460 \pm 30$ & $\begin{array}{l}760(26.5 \%) 680 \mathrm{BC} \\
670(68.9 \%) 410 \mathrm{BC}\end{array}$ \\
\hline 35 & $\mathrm{CB}$ & KIA-comb: $2500 \pm 60$ & $\begin{array}{l}800(87.3 \%) 480 \mathrm{BC} \\
470 \quad(8.1 \%) 410 \mathrm{BC}\end{array}$ \\
\hline 36 & $\mathrm{CB}$ & KIA-30041: $2480 \pm 30$ & $\begin{array}{l}770(90.9 \%) 480 \mathrm{BC} \\
470(4.5 \%) 410 \mathrm{BC}\end{array}$ \\
\hline 57 & $\mathrm{CB}$ & KIA-30042: $2215 \pm 30$ & $380(95.4 \%) 200 \mathrm{BC}$ \\
\hline 65 & $\mathrm{CB}$ & KIA-35364: $2515 \pm 30$ & $790(95.4 \%) 530 \mathrm{BC}$ \\
\hline 68 & $\mathrm{CC}$ & KIA-34157: $2875 \pm 30$ & $\begin{array}{c}1190(1.4 \%) 1170 \mathrm{BC} \\
1160(1.7 \%) 1140 \mathrm{BC} \\
1130(88.1 \%) 970 \mathrm{BC} \\
960(4.2 \%) 930 \mathrm{BC}\end{array}$ \\
\hline 71 & $\mathrm{CB}$ & KIA-34887: $2320 \pm 30$ & $\begin{array}{l}490(1.0 \%) 460 \mathrm{BC} \\
420(87.3 \%) 350 \mathrm{BC} \\
290(7.2 \%) 230 \mathrm{BC}\end{array}$ \\
\hline 75 & $\mathrm{CC}$ & KIA-35796: $2490 \pm 30$ & $\begin{array}{l}750(15.7 \%) 680 \mathrm{BC} \\
670(4.0 \%) 640 \mathrm{BC} \\
560(75.8 \%) 400 \mathrm{BC}\end{array}$ \\
\hline 75 & $\mathrm{CB}$ & KIA-34922: $2420 \pm 30$ & $\begin{array}{l}750(15.7 \%) 680 \mathrm{BC} \\
670(4.0 \%) 640 \mathrm{BC} \\
560(75.8 \%) 400 \mathrm{BC}\end{array}$ \\
\hline 75 & Comb. & R-Combine: $2455 \pm 21$ & $\begin{array}{l}760(29.8 \%) 680 \mathrm{BC} \\
670(12.9 \%) 610 \mathrm{BC} \\
600(52.7 \%) 410 \mathrm{BC}\end{array}$ \\
\hline 83 & $\mathrm{CB}$ & KIA-34893: $2435 \pm 35$ & $\begin{array}{l}760(20.8 \%) 680 \mathrm{BC} \\
670(8.7 \%) 610 \mathrm{BC} \\
600(65.9 \%) 400 \mathrm{BC}\end{array}$ \\
\hline 84 & $\mathrm{CC}$ & IRPA-476: $2430 \pm 50$ & $\begin{array}{l}760(20.1 \%) 680 \mathrm{BC} \\
670(75.3 \%) 400 \mathrm{BC}\end{array}$ \\
\hline 86 & $\mathrm{CB}$ & KIA-34180: $2390 \pm 30$ & $\begin{array}{l}730(5.5 \%) 690 \mathrm{BC} \\
550(89.9 \%) 390 \mathrm{BC}\end{array}$ \\
\hline 87 & $\mathrm{CC}$ & IRPA-477: $2410 \pm 55$ & $\begin{array}{l}760(17.9 \%) 680 \mathrm{BC} \\
670(77.5 \%) 390 \mathrm{BC}\end{array}$ \\
\hline 91 & $\mathrm{CB}$ & KIA-34179: $2400 \pm 30$ & $\begin{array}{l}740(8.2 \%) 690 \mathrm{BC} \\
660(1.2 \%) 650 \mathrm{BC} \\
550(85.9 \%) 390 \mathrm{BC}\end{array}$ \\
\hline
\end{tabular}

${ }^{\mathrm{a}} \mathrm{CB}=$ cremated bone $; \mathrm{CC}=$ charcoal. 
Two graves are dated in the Late Bronze Age. The oldest absolutely dated grave (68) in the site fits in the phase Ha A2-B1 (KIA-34157: 1190-1170 [1.4\%], 1160-1140 [1.7\%], 1130-970 [88.1\%], 960-930 [4.2\%] cal BC). It has been obtained on CC. The second ${ }^{14} \mathrm{C}$ date (KIA-34923: $980-820$ [95.4\%] cal BC) comes from an urn grave that had been disturbed by one of the younger Iron Age quadrangular monuments. It is the only Late Bronze Age cremation that is located in the Early Iron Age area of the cemetery.

The other ${ }^{14} \mathrm{C}$ dates cover the Iron Age. These dates were obtained from graves with or without an urn. Most of the graves are chronologically situated in the expected Early Iron Age period. Surprisingly, some cremations belong to the Late Iron Age. This period was not recognized in the former study of the site based on a typochronological analysis from the funerary pottery. The pottery from the beginning of the Late Iron Age (La Tène I) is characterized by typical sharp biconical shapes like the situlae and carinated bowls. Due to the lack of this kind of ceramics, the cemetery was assumed to stop at the end of the Early Iron Age around $500 \mathrm{BC}$. On the basis of the available ${ }^{14} \mathrm{C}$ dates, the occupation period of the cemetery continues until the 2 nd-1st century BC. As already assessed for the Late Bronze Age in Belgium, some aspects of the typochronology for the Iron Age pottery will also have to be revised (De Mulder et al. 2007).

The ${ }^{14} \mathrm{C}$ dates have shed new light on the dating of the funeral monuments of Destelbergen. A hypothesis has been put forward that the circular monument was the oldest phase of the site, going back to Ha A2. It played a pivotal role in the organization of the cemetery. The central grave (91), a "bonepackgrave," has now been dated (KIA-34179: 740-690 [8.2\%], 660-650 [1.2\%], 550-390 [85.9\%] cal BC). This cremation can therefore be dated some time between the mid-8th century to the beginning of the 4th century BC, meaning that it belongs also to the Early Iron Age occupation of the site.

The quadrangular monuments in the Early Iron Age area were dated in the $\mathrm{Ha} \mathrm{C}$ period on basis of the urns of some central graves in these structures (Figure 5). Three of them have their central grave dated on $\mathrm{CB}$. One date corresponds with the assumed chronological attribution to the Early Iron Age (grave 12: KIA-34892: 790-510 [95.4\%] cal BC). The results for the 2 other cremations are younger. Both grave 71 (KIA-34887: 490-460 [1.0\%], 420-350 [87.3\%], 290-230 [7.2\%] cal BC) and grave 57 (KIA-30042: 380-200 [95.4\%] cal BC) can be dated between the 5th and 3rd century BC.

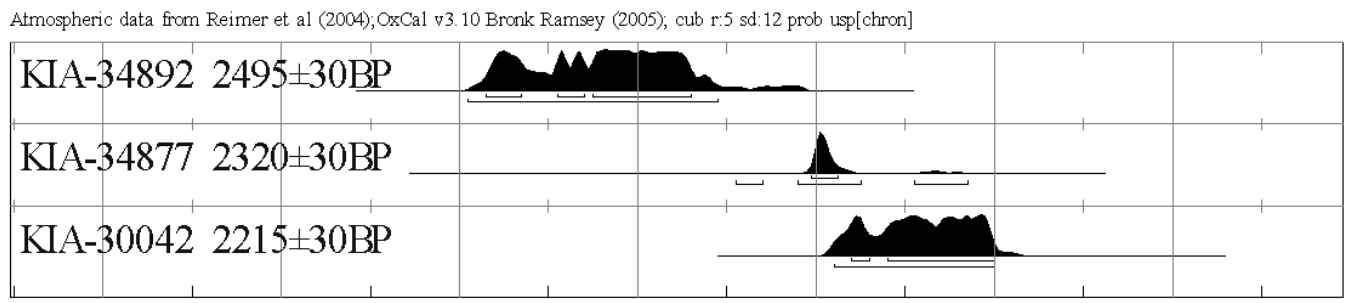

1200CalBC $1000 \mathrm{CalBC} 800 \mathrm{CalBC}$ 600CalBC 400CalBC 200CalBCCalBC/CalAD

\section{Calibrated date}

Figure $5{ }^{14} \mathrm{C}$ dates of the central graves in the quadrangular monuments at Destelbergen

\section{Tessenderlo}

After a visual quality control concerning the degree of cremation, 17 samples were selected for dating (Table 3). Twelve ${ }^{14} \mathrm{C}$ dates were obtained on cremated bone (CB) samples and 5 on charcoal 
(CC). Five of the cremation graves were double dated. The results from the $\mathrm{CC}$ and $\mathrm{CB}$ of graves 14 and 13 were the same. An identical date for both samples from grave 36 is possible. For both cremation graves 43 and 19, the CC date is significantly older than the CB date. It seems reasonable to interpret this difference as the result of the "old wood" effect (Table 4) (Lanting et al. 2001).

Table $3{ }^{14} \mathrm{C}$ dates from the urnfield cemetery at Tessenderlo.

\begin{tabular}{cllc}
\hline \# grave & Material & Lab ID and date BP & Calibrated date $(2 \sigma)$ \\
\hline 2 & CB & KIA-34153: $2710 \pm 30 \mathrm{BP}$ & $920(95.4 \%) 800 \mathrm{BC}$ \\
13 & $\mathrm{CB}$ & KIA-33612: $2795 \pm 30 \mathrm{BP}$ & $1020(95.4 \%) 840 \mathrm{BC}$ \\
13 & $\mathrm{CC}$ & KIA-33631: $2790 \pm 30 \mathrm{BP}$ & $1010(95.4 \%) 840 \mathrm{BC}$ \\
14 & $\mathrm{CC}$ & KIA-33814: $3210 \pm 30 \mathrm{BP}$ & $1530(95.4 \%) 1410 \mathrm{BC}$ \\
14 & $\mathrm{CB}$ & KIA-33618: $3210 \pm 30 \mathrm{BP}$ & $1530(95.4 \%) 1410 \mathrm{BC}$ \\
15 & $\mathrm{CB}$ & KIA-34145: $2790 \pm 30 \mathrm{BP}$ & $1010(95.4 \%) 840 \mathrm{BC}$ \\
19 & $\mathrm{CC}$ & KIA-33614: $2890 \pm 30 \mathrm{BP}$ & $1210(95.4 \%) 970 \mathrm{BC}$ \\
19 & $\mathrm{CB}$ & KIA-33616: $2715 \pm 30 \mathrm{BP}$ & $980(95.4 \%) 800 \mathrm{BC}$ \\
20 & $\mathrm{CB}$ & KIA-33830: $2835 \pm 30 \mathrm{BP}$ & $1120(1.4 \%) 1100 \mathrm{BC}$ \\
& & & $1090(94.0 \%) 910 \mathrm{BC}$ \\
27 & $\mathrm{CB}$ & KIA-34146: $2695 \pm 30 \mathrm{BP}$ & $905(95.4 \%) 800 \mathrm{BC}$ \\
32 & $\mathrm{CB}$ & KIA-33831: $2780 \pm 30 \mathrm{BP}$ & $1010(95.4 \%) 840 \mathrm{BC}$ \\
34 & $\mathrm{CB}$ & KIA-33844: $3500 \pm 35 \mathrm{BP}$ & $1930(95.4 \%) 1730 \mathrm{BC}$ \\
36 & $\mathrm{CB}$ & KIA-33619: $2850 \pm 30 \mathrm{BP}$ & $1120(95.4 \%) 920 \mathrm{BC}$ \\
36 & $\mathrm{CC}$ & KIA-33617: $2800 \pm 30 \mathrm{BP}$ & $1040(91.1 \%) 890 \mathrm{BC}$ \\
& & & $880(4.3 \%) 840 \mathrm{BC}$ \\
43 & $\mathrm{CC}$ & KIA-33813: $3010 \pm 30 \mathrm{BP}$ & $1390(95.4 \%) 1120 \mathrm{BC}$ \\
43 & $\mathrm{CB}$ & KIA-33615: $2825 \pm 25 \mathrm{BP}$ & $1050(95.4 \%) 910 \mathrm{BC}$ \\
45 & $\mathrm{CB}$ & KIA-33845: $2710 \pm 35 \mathrm{BP}$ & $920(95.4 \%) 800 \mathrm{BC}$ \\
\hline
\end{tabular}

The oldest ${ }^{14} \mathrm{C}$ date on the site of Tessenderlo goes back to the 20th to 18 th century BC (KIA33844). This date is too old according to the accepted archaeological framework. The CB sample was recovered from an urn grave. The technical characteristics of this urn do not fit with the known pottery manufacturing style for the proposed absolute date. It seems plausible that the CB sample was contaminated by secondary carbonate (Van Strydonck et al. 2009).

The supposed central grave (14) of the ring ditch structure was chronologically located between 1530-1410 [95.4\%] cal BC (see Table 3). The results of the CC and CB samples obtained the same calibrated age. This is much older than traditionally is accepted for the start of the urnfield cemeteries. There is a chronological gap between this funerary monument and the installation in this zone of the urnfield cemetery. If we assume that the 2 CC dates of graves 19 (KIA-33614) and 43 (KIA33614) are too old due to the "old wood" effect, the first cremation graves of the urnfield go back to the late 12 th-11th century $\mathrm{BC}$. All the ${ }^{14} \mathrm{C}$ dates point to an occupation in the Late Bronze Age (see Table 3). The functioning of the site stops in the 9th century BC, before the start of the Early Iron Age.

Table 4 Correspondence table between cremated bone (CB) and charcoal (CC) dates from Tessenderlo.

\begin{tabular}{lllc}
\hline \# grave & CB & CC & Difference $(\mathrm{CC}-\mathrm{CB})$ \\
\hline 14 & $3210 \pm 30 \mathrm{BP}$ & $3210 \pm 30 \mathrm{BP}$ & $0 \pm 42$ \\
43 & $2825 \pm 25 \mathrm{BP}$ & $3010 \pm 30 \mathrm{BP}$ & $185 \pm 39$ \\
19 & $2715 \pm 30 \mathrm{BP}$ & $2890 \pm 30 \mathrm{BP}$ & $175 \pm 42$ \\
36 & $2850 \pm 30 \mathrm{BP}$ & $2800 \pm 30 \mathrm{BP}$ & $-50 \pm 42$ \\
13 & $2795 \pm 30 \mathrm{BP}$ & $2790 \pm 30 \mathrm{BP}$ & $-5 \pm 42$ \\
\hline
\end{tabular}




\section{${ }^{14} \mathrm{C}$ RESULTS FOR THE LATE BRONZE AGE AND EARLY IRON AGE CEMETERIES}

This overview of urnfield cemeteries that have been dated since the introduction of the method for dating cremated bones shows some interesting results (Table 5). In Belgium as well as in northern France, 9 cemeteries are documented; in the Netherlands there are 19. Most dates were performed on cremated bones (CB). In some cases, the charcoal (CC) dates were used to control the ${ }^{14} \mathrm{C}$ dates of cremated bones.

Table 5 Overview of the urnfield sites in Belgium, the Netherlands, and northern France where recent ${ }^{14} \mathrm{C}$ dating projects have been carried out, especially on cremated bones.

\begin{tabular}{|c|c|c|c|c|}
\hline Site & Total ${ }^{14} \mathrm{C}$ dates & CB dated & $\mathrm{CC}$ dated & Inhumation \\
\hline \multicolumn{5}{|l|}{ Belgium } \\
\hline Beerse & 2 & 2 & - & - \\
\hline Blicquy & 19 & 15 & 4 & - \\
\hline Couvin & 3 & - & - & 3 \\
\hline Destelbergen & 22 & 16 & 6 & - \\
\hline Kontich & 7 & 6 & 1 & - \\
\hline Neerharen-Rekem & 15 & 15 & - & - \\
\hline Tessenderlo & 17 & 12 & 5 & - \\
\hline Velzeke/Paddestraat & 26 & 21 & 5 & - \\
\hline Velzeke/Provinciebaan & 10 & 8 & 2 & - \\
\hline \multicolumn{5}{|l|}{ Northern France } \\
\hline Changis-sur-Marne I & 8 & 8 & - & - \\
\hline Changis-sur-Marne II & 3 & 3 & - & - \\
\hline La Croix-Saint-Ouen & 3 & 2 & - & 1 \\
\hline Mareuil-lès-Meaux & 2 & 2 & - & - \\
\hline Marolles-sur-Seine & 14 & 8 & - & 6 \\
\hline Presles-et-Boves & 10 & 10 & - & - \\
\hline Saumeray & 2 & 2 & - & - \\
\hline Thourotte & 3 & 3 & - & - \\
\hline Verneuil-en-Halatte & 2 & 2 & - & - \\
\hline \multicolumn{5}{|l|}{ Southern Netherlands } \\
\hline Beegden & 4 & 4 & - & - \\
\hline De Heibloem & 4 & 2 & 2 & - \\
\hline Geldrop-Mierlo & 5 & 2 & 3 & - \\
\hline Goirle & 6 & 3 & 3 & - \\
\hline Haps & 6 & 5 & 1 & - \\
\hline Lent "Schoolstraat" & 1 & - & - & 1 \\
\hline Lent "Smitjesland" & 3 & 3 & - & - \\
\hline Lent "Steltsestraat" & 3 & 2 & - & 1 \\
\hline Maastricht & 1 & 1 & - & - \\
\hline Nijmegen-Ressen & 1 & 1 & - & - \\
\hline Sint-Oedenrode & 4 & 1 & 3 & - \\
\hline Sittard-Hoogveld 3 & 1 & 1 & - & - \\
\hline Sittard-Hoogveld 4 & 13 & 7 & 6 & - \\
\hline Sittard-Hoogveld 8 & 1 & 1 & - & - \\
\hline Someren "Waterdael" & 12 & 6 & 6 & - \\
\hline Stein & 1 & 1 & - & - \\
\hline Vlodrop & 4 & 2 & 2 & - \\
\hline Weert "Kampershoek" & 1 & 1 & - & - \\
\hline Weert "Klein Leuken" & 2 & 2 & - & - \\
\hline
\end{tabular}


Some results on inhumation graves are also available. Inhumations are exceptional during the period under examination, cremation being the preferred funeral ritual. The results from the ${ }^{14} \mathrm{C}$ dates show an interesting chronological and regional difference. At the sites of Marolles-sur-Seine and Changissur-Marne in the area of the Seine-Marne, a few inhumations were excavated that represent the Early and Middle Bronze Age occupation phases in both cemeteries. However, both sites contain an isolated inhumation, which was younger and belonged to the middle phase of the Late Bronze Age (Ly-8278: 1220-910 [95.4\%] cal BC; Ly 9034: 1120-1100 [1.3\%], 1090-840 [94.3\%] cal BC) (Peake and Delattre 2005). Another ${ }^{14} \mathrm{C}$ date for an inhumation grave in northern France comes from the site of La Croix-Saint-Ouen "Parc Scientifique," which is comparable to the date of Changissur-Marne (Beta-127045: 1130-800 [95.4\%] cal BC) (Blanchet and Talon 2005). A specific site is the cave La Roche Alberic in Couvin (Belgium). In one of the cave's chambers, 3 human skulls were found. They have been interpreted as a ritual deposition in a sacred place instead of funerary remains (Cattelain 2002). Three ${ }^{14} \mathrm{C}$ dates have been obtained for these skulls. Surprisingly, all 3 dates belong to the Late Bronze Age with a range between 1160-1140 [1.0\%], 1130-970 [94.4\%] cal BC (KIA-25607) and 900-860 [8.6\%], 850-790 [86.8\%] cal BC (KIA-25608) (Robertz 2008). Finally, at Nijmegen-Lent in the southern Netherlands, 3 inhumations from 2 different burial sites are dated to the Early Iron Age. One was an isolated grave in a settlement context. The other inhumations were discovered in an urnfield cemetery together with contemporary cremations (van den Broeke 2008).

An overview of the ${ }^{14} \mathrm{C}$ dates on cremated bones shows that only a limited number of sites were dated by more than 10 dates. This is due to the scientific aims behind the different dating projects. A lot of sites with limited numbers of ${ }^{14} \mathrm{C}$ dates on cremated bones were used to test the validity of the method. Other dates were available due to recent rescue excavations at cemetery sites. Because the method of dating cremated bones is relatively new, it is more frequently used in ongoing excavations than on material from older excavations. The relatively higher number of ${ }^{14} \mathrm{C}$ dates for the Belgian sites is the result of a sponsored scientific project to date some already excavated urnfield cemeteries.

\section{DISCUSSION}

The ${ }^{14} \mathrm{C}$ dates in the studied region of northern France, Belgium, and the southern Netherlands tend to modify the concept of the evolution of the funerary landscape in the Bronze and Early Iron ages.

\section{Middle Bronze Age}

Recent studies of ${ }^{14} \mathrm{C}$ dates from the Early and Middle Bronze Age barrows showed an interesting phenomenon in the studied area. A change in the burial ritual took already place during the Middle Bronze Age. According to the ${ }^{14} \mathrm{C}$ dates, an important peak of erecting barrows is attested between 1800-1500 BC in the Flemish sandy region (Bourgeois and Cherretté 2005). Some younger dates suggest that these barrows stayed in use until around 1100 BC (Bourgeois et al. 1996). The main phase of constructing barrows in northern France also points to the same period between 1800-1500 BC (Toron 2006). Research for the occupation history of the barrows in the Netherlands showed related information. The main period of barrow construction and associated primary burials is also concentrated between 1800-1500 BC. Secondary burials prove that they stayed in use after 1500 BC (Middle Bronze Age B) (Bourgeois and Arnoldussen 2006).

\section{Middle Bronze Age-Late Bronze Age Transition}

The study area was a part of the Atlantic world during the Bronze Age. Traditionally, it is accepted that around 1125-1100 BC (about 3000-2950 BP), this region was under the economic and cultural 
influence of the central European RSFO (Rhin-Suisse-France orientale) group during its dynamic expansion (phase 2). The Seine-Marne region, which forms the border area between the 2 complexes, had already come under the influence of the RSFO group. The appearance of the urnfield cemeteries, with their cremation flat graves, is seen as part of the central European influence in western Europe. These urnfields were constructed away from the traditional barrow cemeteries. The start of the Late Bronze Age seems to be a clear cultural break with the former funerary rituals and places.

The results from the recent ${ }^{14} \mathrm{C}$ dates on different sites show a more diversified and complicated view from that of funerary traditions seen between $1500-1100 \mathrm{BC}$ in the different regions of this study. In the Seine and Marne region of northern France, different funerary sites with a Middle Bronze Age occupation between 1500-1100 BC are recorded. Some differ from the other sites in the study area. At the Marolles-sur-Seine site, 6 out of 9 inhumations have been dated. They represent the Early and Middle Bronze Age occupation phases of the site. The ${ }^{14} \mathrm{C}$ dates cover a period from $\sim 3545 \mathrm{BP}$ (Ly8279 ) to $\sim 3170$ BP (GrA-17981). A few of the cremations already date to the 15 th century BC, like the graves 13 (GrA-17935: 1460-1200 [95.4\%] cal BC) and 48 (GrA-17937: 1500-1260 [95.4\%] cal BC; GrA-21754: 1430-1190 [92.1\%], 1180-1130 [3.3\%] cal BC) (Peake et al. 2005). A similar pattern can be seen at Changis-sur-Marne. Two inhumations there are older and belong to the Early Bronze Age and the beginning of the Middle Bronze Age (Lafage F, personal communication by email 31 August 2008).

Two cremation graves at Changis-sur-Marne have the same age (Middle Bronze Age) according to the ${ }^{14} \mathrm{C}$ results on CB (GrA-19569: 1610-1400 [95.4\%] cal BC; GrA-32250: 1610-1590 [1.1\%], $1540-1410$ [94.3\%] cal BC). They represent the beginning of the cremation phase. The 2 cremation groups at Changis-sur-Marne also show a continual use from around the 15th century BC until the end of the Late Bronze Age (Lafage et al. 2007). The Mareuil-lès-Meaux site is also dated to the final phase of the Middle Bronze Age; both dates are situated at about 3220-3200 BP (GrA-20608, GrA-20609) (Cottiaux et al. 2001).

In the other areas of the study region, the tradition of urnfield cemeteries does not go back that far in time, but the ${ }^{14} \mathrm{C}$ dates from some sites show they are older than the previously assumed date of $\sim 1125 / 1100 \mathrm{BC}$ (beginning of Ha A2). Some burial sites came into use in the first phase of the Late Bronze Age (Bz D-Ha A1). The oldest cremation, a bonepackgrave at Verneuil-en-Halatte in the Oise Valley, is as old as 1540-1370 [93.9\%], 1340-1320 [1.5\%] cal BC (GrA-19556). The other date for this site obtained on an urn grave was slightly younger (GrA-19557: 1460-1250 [95.4\%] cal $\mathrm{BC}$ ). Both dates demonstrate that this cemetery was in use during the transition from the Middle Bronze Age to the Late Bronze Age (Bronze final I according to the French chronology) (Gaudefroy and Le Goff 2004). Other sites in the Oise Valley that can be located in this period are La CroixSaint-Ouen and Thourrote. The funerary site of Croix-Saint-Ouen "Parc Scientifique" consists of a round barrow measuring $22 \mathrm{~m}$ and containing 2 cremations and a group of 7 cremations and 3 inhumations in the neighborhood of the monument. The barrow dates to the Middle Bronze Age based on the typochronology of the urn grave. Cremated bone from a grave on the outskirts of the monument is dated to $1420-1130$ [95.4\%] cal BC (GrA-14511) (Blanchet and Talon 2005). The cemetery of Thourotte is structured in 3 groups of 18 cremation graves. In 2 of these groups, respectively a round barrow and a long rectilinear funerary structure (langebed) were discovered. The oldest date goes back to 1320-1010 [95.4\%] cal BC (GrA-14514). The youngest is dated to 1260-970 [94.4\%] 960-940 [1.0\%] cal BC (GrA-14978) (Blanchet et al. 2005). 
New information for some Belgian sites is also available. A previous study established an early start for the cemetery at Blicquy. The urnfield covers the period from the 14th until the beginning of the 10 th century $\mathrm{BC}$, although one of the graves in Blicquy was earlier than the other ${ }^{14} \mathrm{C}$ dates (KIA23752: 1520-1410 [95.4\%] cal BC) (De Mulder et al. 2007). A similar interpretation applies to the site of Tessenderlo in the eastern part of Belgium. This Late Bronze Age cemetery is preceded by an open-ring ditch with a central cremation grave of the Brandgrubengrab type. It is dated to the late 16th-15th century BC (see Table 3). Recent dates from the urnfield at Neerharen-Rekem show this funerary site starts in the 14th century BC (Van Impe, personal communication, 2008). At Beerse, a langebed surrounded by a triple row of postholes was excavated. Two cremation graves were uncovered, one of them inside the monument. These were younger than the previously mentioned Belgian ${ }^{14} \mathrm{C}$ dates from Blicquy, Tessenderlo and Neerharen-Rekem, but belong to the transitional period between Ha A1 and Ha A2. They dated to 1270-1020 [95.4\%] cal BC (KIA-32362) and 1270-1040 [95.4\%] cal BC (KIA-33613) for the urn grave inside the monument (Delaruelle et al. 2008).

Dates from the southern Netherlands also suggest an earlier start than Ha A2. Some of these dates were obtained on cremated bone from graves in urns of the Laren type or related shapes. At Lent "Smitjesland," a small cemetery with 10 cremation graves was excavated. The urns still resemble a Middle Bronze Age tradition but are of a better quality. ${ }^{14} \mathrm{C}$ dates on 3 cremated bone samples place it in the 12th to first half of the 11th century BC (van den Broeke 2001). Isolated graves were found in 2 places close to the urnfield of Sittard-Hoogveld. Two dates prove their age: 1390-1050 [95.4\%] cal BC (GrA-15829) and 1440-1120 [95.4\%] cal BC (GrA-16366) (Lanting and van der Plicht 2001/2002). In the urnfield of Haps and Sint-Oedenrode-Haagakkers, 2 dates from this early phase were also obtained from cremation graves by Laren style pottery (Lanting and van der Plicht 2001/ 2002).

\section{Span of the Urnfield Cemeteries}

From Ha A2 on, urnfield cemeteries start to flourish in northern France, Belgium, and the Netherlands. The archaeological documentation about these sites is extensive because research began during the 19th century. Typochronological study of these cemeteries dated their use to the Early Iron Age. Depending on the area, regional differences can be ascertained based on the ${ }^{14} \mathrm{C}$ results of the studied sites.

The available ${ }^{14} \mathrm{C}$ dates for northern French urnfields point to an important occupation period during the Late Bronze Age. The ${ }^{14} \mathrm{C}$ dates from the site of Presles-et-Boves in the Aisne Valley cover a period from $\sim 2970$ BP (GrA-22783) until 2695 BP (GrA-22785) (Figure 6). The cemetery seems to function from Ha A1 until Ha B2/3 (Le Guen and Pinard 2007). The site at Marolles-sur-Seine is also in use during the Late Bronze Age. Next to the cremation graves, there is also 1 inhumation, which is younger than the other inhumations in the cemetery and belongs to the middle phase of the Late Bronze Age (Ly-8278: 1220-910 [95.4\%] cal BC). The Early Iron Age phase is only represented by 1 dated cremation at the site of Marolles-sur-Seine. Structure 49 was dated to $850-720$ [60.5\%], 700-530 [34.9\%] cal BC (GrA-17939) (Peake et al. 2005).

Other urnfields in northern France, mentioned in this paper, also show a less documented Early Iron Age occupation. At Changis-sur-Marne, a single cremation was dated in this period (GrA-32443: 810-740 [75.3\%], 690-660 [11.2\%], 650-590 [7.9\%], 580-560 [1.0\%] cal BC) (Lafage et al. 2007). In the area of Seine-Marne, a change in the archaeological record is observed. The cemeteries are disappearing from the known archaeological record and are replaced by evidence of settlements (Peake 2007). 


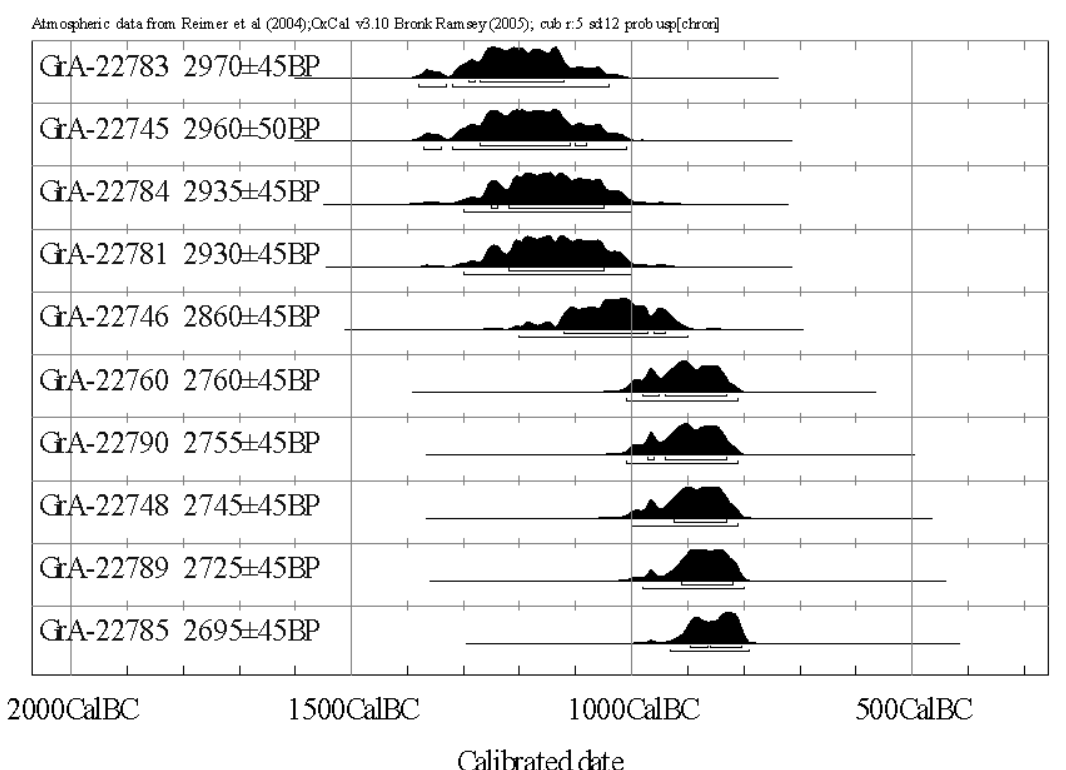

Figure $6{ }^{14} \mathrm{C}$ dates of the Late Bronze Age urnfield cemetery at Presles-et-Boves (Le Guen et al. 2007).

In western Belgium, the archaeological record shows that a series of urnfields stay in use during the Early Iron Age (De Mulder 1994). This is also demonstrated by the available ${ }^{14} \mathrm{C}$ dates. The urnfield of Destelbergen starts during the Late Bronze Age but its main period is during the Early Iron Age (see Table 3). The cemeteries of Velzeke/Paddestraat and Velzeke/Provinciebaan, which are only separated about $1 \mathrm{~km}$ from each other, exist together for a period during the Early Iron Age (De Mulder et al. 2007). At Blicquy, which was occupied during the Bronze Age, a single urn grave is dated to the Early Iron Age. There is a gap of 2 centuries between this cremation and the youngest grave from the Bronze Age (De Mulder et al. 2007).

The cemeteries in the eastern part of Flanders are part of the "northwestern group," which also covers the southern Netherlands. In this area, there is continuity from the burial practices of the Late Bronze Age, also from the functioning urnfields. Next to the existing funerary sites, numerous new urnfields began in this area during the Early Iron Age (Roymans and Kortlang 1999). The cemetery of Neerharen-Rekem displays continuity from the Bronze Age period on (De Boe et al. 1992), which is supported by the ${ }^{14} \mathrm{C}$ results (Van Impe 2001). The ${ }^{14} \mathrm{C}$ dates from Haps show the same pattern (Lanting and van der Plicht 2001/2002). On the other hand, Tessenderlo only functioned during the Bronze Age (see Table 4). For other urnfields, their appearance in the Early Iron Age is confirmed by the ${ }^{14} \mathrm{C}$ dates. For example, Geldrop-Mierlo was in use during the Early Iron Age (Figure 7) (Hissel et al. 2007). The dated CC from the urnfield at Someren-Waterdael also mainly belongs to the Early Iron Age (Kortlang 1999). The reliability of a younger date for the site is doubtful (Lanting and van der Plicht 2001/2002).

Cremation was the dominant ritual in the urnfield cemeteries, but recently some inhumations have been discovered. At Nijmegen-Lent in the southern Netherlands, 3 inhumations from 2 different burial sites were dated to the Early Iron Age. One was an isolated grave in a settlement context at the site Lent "Schoolstraat," dated to 780-480 [91.6\%], 470-410 [3.8\%] cal BC (GrA-18379) (Lanting and van der Plicht 2001/2002). The other inhumations were discovered in an urnfield cemetery 


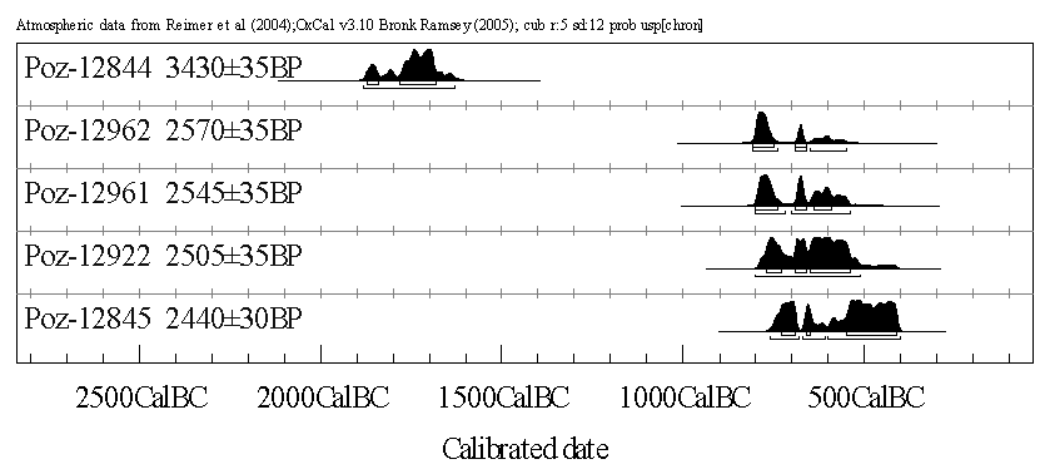

Figure 7 The ${ }^{14} \mathrm{C}$ dates from the Early Iron Age urnfield at Geldrop-Mierlo. One of the dates on charcoal from a ring ditch is too old.

at Lent "Steltstestraat." They dated to 800-720 [37.1\%], 700-540 [58.3\%] cal BC (GrA-18410) and 780-48 [91.6\%], 470-410 [3.8\%] cal BC (GrA-18408). One of the cremations was also dated, and belongs to the same period: 770-400 [95.4\%] cal BC (GrA-18292) (van den Broeke 2008).

\section{The Disappearance of the Urnfield Phenomenon}

Before discussing the disappearance of the urnfield cemeteries, it is necessary to explain the different chronologies used in the study area for the Iron Age. The chronological framework for the Iron Age differs between northern France, Belgium, and the Netherlands (Figure 8). France and Belgium divide this period into an Early and Late Iron Age, Hallstatt and La Tène period, respectively. The latter period starts around 475-450 BC with the appearance of the cultural influence from the Marne region. Distinctive carinated pottery is used as a guide fossil (Bourgeois 1999). In the Netherlands, a 3-phased system is used as an indicator. The emergence of the so-called Marne pottery is used as the boundary between the Early Iron Age and the Middle Iron Age. This happens at the beginning of the 5th century BC (Verwers 1972; van den Broeke 1987). The start of the Late Iron Age is dated to $250 \mathrm{BC}$ when the first glass bracelets are found in the archaeological record (Verwers 1972). This chronological boundary is still used, although new information points to a start around $270 \mathrm{BC}$ (Lanting and van der Plicht 2005/2006).

\begin{tabular}{|l|l|l|}
\hline Years BC & N France/Belgium & The Netherlands \\
\hline 800 & Early Iron Age & Early Iron Age \\
\hline $500 / 450$ & Late Iron Age & Middle Iron Age \\
\cline { 3 - 3 } 250 & & Late Iron Age \\
\hline 0 & Roman period & Roman period \\
\hline
\end{tabular}

Figure 8 Overview of the 2 different chronological frameworks for the Iron Age in the study area.

As already mentioned, the French sites discussed in this article do not yield much information about the Early Iron Age. Except for an isolated dated cremation grave, they appear to have been deserted after the Late Bronze Age period. In the western part of Belgium, the urnfield tradition is usually considered to end at the start of the Late Iron Age, the so-called La Tène period. This transition is archaeologically dated to $475-450 \mathrm{BC}$. The complete absence of any typical Marne pottery in the cemeteries was seen as confirmation that these were abandoned as funerary sites (De Mulder 1994); 
instead, new places were chosen as a burial ground. Furthermore, some changes in the funeral rites were also visible (Bourgeois 1991). Even with the available ${ }^{14} \mathrm{C}$ dates, a precise chronological boundary cannot be established due to the problem of the so-called Hallstatt plateau in the calibration curve, which hinders the refining of the chronological framework for the Early Iron Age and the beginning of the Late Iron Age. Both sites at Velzeke were effectively abandoned as cemeteries at the end of the Early Iron Age (De Mulder et al. 2007). As a result of the ${ }^{14} \mathrm{C}$ dates on cremated bone, the situation of Destelbergen has to be re-assessed (see Table 3). It is clear that the urnfield was in use at least until the $3 \mathrm{rd}$ century BC. One date even suggests that the occupation ultimately ended in the 2nd century or first half of the 1st century BC (KIA-34909: 350-320 [4.7\%], 210-40 [90.7\%] cal $\mathrm{BC})$. This information comes also from urn graves as well as unurned cremations. As already ascertained for the Late Bronze Age period, some further re-evaluation of the typochronological framework based on the pottery studies will be necessary (De Mulder et al. 2007, 2008). The suggested differences between the typochronological dates and the ${ }^{14} \mathrm{C}$ dates for pottery from the Early Iron Age and the beginning of the Late Iron Age have to be confirmed by further research (Figure 9).
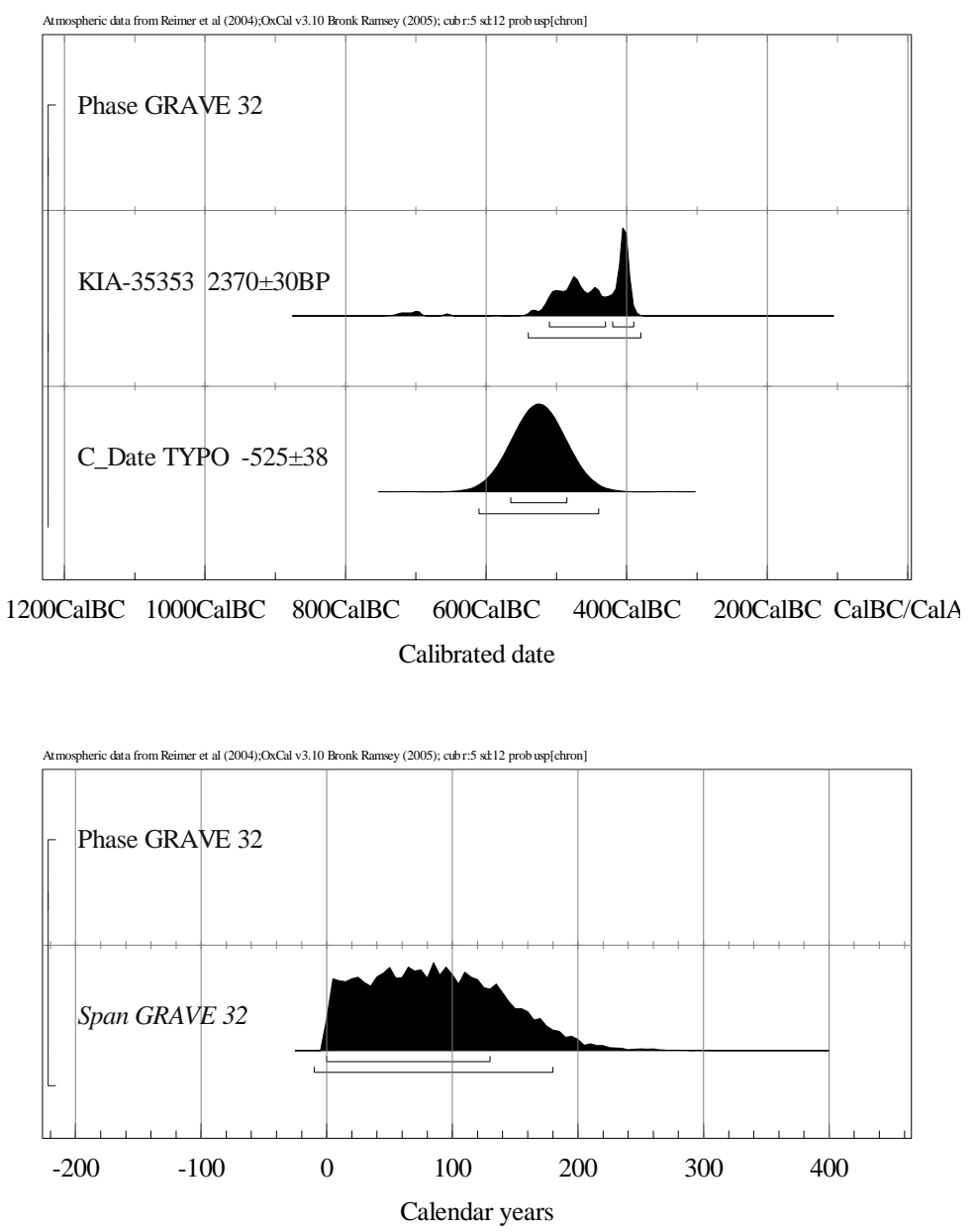

Figure 9 Comparison between the typochronological date and the ${ }^{14} \mathrm{C}$ result from grave 32 at Destelbergen. The urn was dated to the Ha D period (600-450 BC). In the adopted model, this corresponds to a normal distribution of $525 \pm 38 \mathrm{BC}$. The difference between the ${ }^{14} \mathrm{C}$ age $(2370 \pm 30 \mathrm{BP})$ and the typological date is $0-130 \mathrm{yr}$ at $68.2 \%$ probability and -10 to $180 \mathrm{yr}$ at $95.4 \%$ probability. 
In the eastern part of Belgium and the southern Netherlands, there were already archaeological indications that although many urnfields came to a halt at the end of the Early Iron Age, some stayed in use longer. They were functioning until the end of the 5th century BC (Hessing and Kooi 2005). The funerary gifts of carinated pottery at sites like Lommel/Kattenbosch were an indication that some cemeteries survived into the Early La Tène period (De Laet and Marien 1950). The urnfield of Rijkevorsel/Hellehoeksheide covers also the period between the Early Iron Age and the Early La Tène until 400 BC on basis of the excavated pottery (Theunissen 1993). At Someren "Waterdael," an inhumation grave at the northwest border of the urnfield reflects usage until at least the Middle Iron Age ( $\sim 400 \mathrm{BC})$ of the site. This date is based on a carinated pot that was put into the burial as a funeral gift (Kortlang 1999). Another archaeological element that was seen as a chronological marker for the Middle Iron Age was the appearance of rectilinear peripheral ditches in some of the urnfields (Gerritsen 2003). This is confirmed by former ${ }^{14} \mathrm{C}$ dates on $\mathrm{CC}$ samples from the infilling of the ditch (Lanting and van der Plicht 2005/2006).

These archaeological assumptions are challenged by the results from the cremated bone (CB) dates. At Neerharen-Rekem, one of the graves goes back to the end of the Middle Iron Age, between 400200 cal BC (Van Impe, personal communication, 2008). This is younger than expected for the final phase of the urnfields in this region. The CC from a flatgrave at Someren "Waterdael" produced an age of 540-340 [70.0\%], 320-200 [25.4\%] cal BC (GrN-22197). However, there are some doubts about the validity of this date (Lanting and van der Plicht 2001/2002). Otherwise, it is supported by the presence of an inhumation grave from the Middle Iron Age. At Sitttard Hoogveld 4, an urnfield of the Early Iron Age to the beginning of the Middle Iron Age was excavated (Tol 2000). Two ${ }^{14} \mathrm{C}$ dates on $\mathrm{CB}$ from grave 32 delivered an age of 770-480 [86.0\%], 470-410 [9.4\%] cal BC (GrA15190/15471). There seems to be no chronological continuity between the Early Iron Age urnfield and the younger cemetery of the beginning of the Dutch Late Iron Age. The ${ }^{14} \mathrm{C}$ dates on the urnfield cover a period between $\sim 2280$ BP (GrA-23439) to $\sim 2135$ BP (GrA-23444) (Table 6) (Lanting and van der Plicht 2005/2006).

Table 6 Overview of external ${ }^{14} \mathrm{C}$ dates from the Belgian, French, and Dutch sites mentioned in the discussion.

\begin{tabular}{|c|c|c|c|}
\hline \# grave & Material & Lab ID and date BP & Calibrated date $(2 \sigma)$ \\
\hline \multicolumn{4}{|c|}{ Beerse (Antwerp, B.) } \\
\hline MEZ04-1-13 & $\mathrm{CB}$ & KIA-32362: $2935 \pm 35$ & $1270(95.4 \%) 1020 \mathrm{BC}$ \\
\hline M53 & $\mathrm{CB}$ & KIA-33613: $2945 \pm 30$ & $1270(95.4 \%) 1040 \mathrm{BC}$ \\
\hline M75 & $\mathrm{CC}$ & KIA-33580: $2325 \pm 25$ & $420(95.4 \%) 360 \mathrm{BC}$ \\
\hline \multicolumn{4}{|c|}{ Changis-sur-Marne (Seine-et-Marne, Fr.) } \\
\hline St1484 & Bone & Ly-9034: $2810 \pm 45$ & $\begin{array}{l}1120(1.3 \%) 1100 \mathrm{BC} \\
1090(94.3 \%) 840 \mathrm{BC}\end{array}$ \\
\hline St2765 & $\mathrm{CB}$ & GrA-19569: $3205 \pm 45$ & $1610(95.4 \%) 1400 \mathrm{BC}$ \\
\hline St3120 & $\mathrm{CB}$ & GrA-32250: $3205 \pm 35$ & $\begin{array}{l}1610(1.1 \%) 1590 \mathrm{BC} \\
1540(94.3 \%) 1410 \mathrm{BC}\end{array}$ \\
\hline St3508 & $\mathrm{CB}$ & GrA-32443: $2575 \pm 30$ & $\begin{array}{l}810(75.3 \%) 740 \mathrm{BC} \\
690(11.2 \%) 660 \mathrm{BC} \\
650(7.9 \%) 590 \mathrm{BC} \\
580(1.0 \%) 560 \mathrm{BC}\end{array}$ \\
\hline \multicolumn{4}{|c|}{ Couvin (Namur, B.) } \\
\hline CRA25015 & Bone & KIA-25608: $2665 \pm 25$ & $\begin{array}{l}900(8.6 \%) 860 \mathrm{BC} \\
850(86.8 \%) 790 \mathrm{BC}\end{array}$ \\
\hline CRA25101 & Bone & KIA-25607: $2880 \pm 25$ & $\begin{array}{l}1160(1.0 \%) 1140 \mathrm{BC} \\
1130(94.4 \%) 970 \mathrm{BC}\end{array}$ \\
\hline
\end{tabular}


Table 6 Overview of external ${ }^{14} \mathrm{C}$ dates from the Belgian, French, and Dutch sites mentioned in the discussion. (Continued)

\begin{tabular}{|c|c|c|c|}
\hline \# grave & Material & Lab ID and date BP & Calibrated date $(2 \sigma)$ \\
\hline CRA25201 & Bone & KIA-25606: $2840 \pm 25$ & $\begin{array}{l}1120(1.0 \%) 1100 \mathrm{BC} \\
1090(94.4 \%) 910 \mathrm{BC}\end{array}$ \\
\hline \multicolumn{4}{|c|}{ La Croix-Saint-Ouen (Oise, Fr.) } \\
\hline St6 & $\mathrm{CB}$ & GrA-14511: $3035 \pm 45$ & $1420(95.4 \%) 1130 \mathrm{BC}$ \\
\hline St42 & Bone & Beta-127045: $2880 \pm 70$ & $1130(95.4 \%) 800 \mathrm{BC}$ \\
\hline \multicolumn{4}{|c|}{ Lent 'Schoolstraat' (Gelderland, N.) } \\
\hline Sh1.1.P.24 & Bone & GrA-18379: $2490 \pm 35$ & $\begin{array}{l}780(91.6 \%) 480 \mathrm{BC} \\
470(3.8 \%) 410 \mathrm{BC}\end{array}$ \\
\hline \multicolumn{4}{|c|}{ Lent 'Smitjesland' (Gelderland, N.) } \\
\hline Si 1.7.P37.95 & $\mathrm{CB}$ & GrA-16977: $2920 \pm 50$ & $1300(95.4 \%) 970 \mathrm{BC}$ \\
\hline Si 1.8.P1.21 & $\mathrm{CB}$ & GrA-16979: $2985 \pm 50$ & $1390(95.4 \%) 1050 \mathrm{BC}$ \\
\hline Si 1.7.P6.45/47 & $\mathrm{CB}$ & GrA-16980: $2915 \pm 45$ & $1270(95.4 \%) 970 \mathrm{BC}$ \\
\hline \multicolumn{4}{|c|}{ Lent 'Steltsestraat' (Gelderland, N.) } \\
\hline S1 2.8.9 & Bone & GrA-18410: $2540 \pm 35$ & $\begin{array}{l}800(37.1 \%) 720 \mathrm{BC} \\
700(58.3 \%) 540 \mathrm{BC}\end{array}$ \\
\hline S1 2.2.35 & Bone & GrA-18408: $2490 \pm 35$ & $\begin{array}{l}780(91.6 \%) 480 \mathrm{BC} \\
470(3.8 \%) 410 \mathrm{BC}\end{array}$ \\
\hline S1 2.1.29 & $\mathrm{CB}$ & GrA-18292: $2460 \pm 50$ & $770(95.4 \%) 400 \mathrm{BC}$ \\
\hline \multicolumn{4}{|c|}{ Mareuil-lès-Meaux (Seine-et-Marne, Fr.) } \\
\hline St40 & $\mathrm{CB}$ & GrA-20608: $3220 \pm 60$ & $\begin{array}{l}1750(90.3 \%) 1490 \mathrm{BC} \\
1480(2.4 \%) 1450 \mathrm{BC}\end{array}$ \\
\hline St199 & $\mathrm{CB}$ & GrA-20609: $3200 \pm 60$ & $\begin{array}{l}1620(93.7 \%) 1370 \mathrm{BC} \\
1340(1.7 \%) 1310 \mathrm{BC}\end{array}$ \\
\hline \multicolumn{4}{|c|}{ Marolles-sur-Seine (Seine-et-Marne, Fr.) } \\
\hline St13 & $\mathrm{CB}$ & GrA-17935: $3080 \pm 50$ & $1460(95.4 \%) 1200 \mathrm{BC}$ \\
\hline St30 & Bone & Ly-8279: $3545 \pm 50$ & $2030(95.4 \%) 1740 \mathrm{BC}$ \\
\hline St38 & Bone & GrA-17981: $3170 \pm 50$ & $1540(95.4 \%) 1310 \mathrm{BC}$ \\
\hline St48 & $\mathrm{CB}$ & GrA-17937: $3130 \pm 50$ & $1500(95.4 \%) 1260 \mathrm{BC}$ \\
\hline St48 & $\mathrm{CB}$ & GrA-21754: $3050 \pm 60$ & $\begin{array}{l}1430(92.1 \%) 1190 \mathrm{BC} \\
1180(3.3 \%) 1130 \mathrm{BC}\end{array}$ \\
\hline St49 & $\mathrm{CB}$ & GrA-19939: $2590 \pm 50$ & $\begin{array}{l}850(60.5 \%) 720 \mathrm{BC} \\
700(34.9 \%) 530 \mathrm{BC}\end{array}$ \\
\hline St104 & Bone & Ly-8278: $2875 \pm 50$ & $1220(95.4 \%) 910 \mathrm{BC}$ \\
\hline \multicolumn{4}{|c|}{ Presles-et-Boves (Aisne, Fr.) } \\
\hline St. 181 & $\mathrm{CB}$ & GrA-22783: $2970 \pm 45$ & $\begin{array}{l}1380(3.9 \%) 1330 \mathrm{BC} \\
1320(91.5 \%) 1040 \mathrm{BC}\end{array}$ \\
\hline St. 269 & $\mathrm{CB}$ & GrA-22785: $2695 \pm 45$ & $930(95.4 \%) 790 \mathrm{BC}$ \\
\hline \multicolumn{4}{|c|}{ Sittard 'Hoogveld 3' (Limburg, N.) } \\
\hline Gr. & $\mathrm{CB}$ & GrA-15829: $2980 \pm 50$ & $1390(95.4 \%) 1050 \mathrm{BC}$ \\
\hline \multicolumn{4}{|c|}{ Sittard ‘Hoogveld 4’ (Limburg, N.) } \\
\hline Gr23 & $\mathrm{CB}$ & GrA-23439: $2280 \pm 45$ & $\begin{array}{l}410(42.7 \%) 340 \mathrm{BC} \\
330(52.7 \%) 200 \mathrm{BC}\end{array}$ \\
\hline Gr32 & $\mathrm{CB}$ & GrA-15190/471: $2480 \pm 45$ & $\begin{array}{l}770(86.0 \%) 480 \mathrm{BC} \\
470(9.4 \%) 410 \mathrm{BC}\end{array}$ \\
\hline Gr82 & $\mathrm{CB}$ & GrA-23444: $2135 \pm 45$ & $\begin{array}{l}360(20.7 \%) 280 \mathrm{BC} \\
260(74.7 \%) 40 \mathrm{BC}\end{array}$ \\
\hline \multicolumn{4}{|c|}{ Sittard ‘Hoogveld 8’' (Limburg, N.) } \\
\hline Gr1 & $\mathrm{CB}$ & GrA-16366: $3050 \pm 60$ & $1440(95.4 \%) 1120 \mathrm{BC}$ \\
\hline
\end{tabular}


Table 6 Overview of external ${ }^{14} \mathrm{C}$ dates from the Belgian, French, and Dutch sites mentioned in the discussion. (Continued)

\begin{tabular}{|c|c|c|c|}
\hline \# grave & Material & Lab ID and date BP & Calibrated date $(2 \sigma)$ \\
\hline \multicolumn{4}{|c|}{ Someren 'Waterdael' (Noord-Brabant, N.) } \\
\hline Gr148 & $\mathrm{CC}$ & GrN-22197: $2320 \pm 50$ & $\begin{array}{l}540(70.0 \%) 340 \mathrm{BC} \\
320(25.4 \%) 200 \mathrm{BC}\end{array}$ \\
\hline \multicolumn{4}{|c|}{ Thourotte (Oise, Fr.) } \\
\hline St2 & $\mathrm{CB}$ & GrA-14514: $2955 \pm 45$ & $1320(95.4 \%) 1010 \mathrm{BC}$ \\
\hline St106 & $\mathrm{CB}$ & GrA-14978: $2905 \pm 45$ & $\begin{array}{r}1260(94.4 \%) 970 \mathrm{BC} \\
960(1.0 \%) 940 \mathrm{BC}\end{array}$ \\
\hline \multicolumn{4}{|c|}{ Verneuil-en-Halatte (Oise, Fr.) } \\
\hline $\mathrm{T} 18$ & $\mathrm{CB}$ & GrA-19556: $3180 \pm 45$ & $\begin{array}{l}1540(93.9 \%) 1370 \mathrm{BC} \\
1340(1.5 \%) 1320 \mathrm{BC}\end{array}$ \\
\hline $\mathrm{T} 20$ & $\mathrm{CB}$ & GrA-19557: $3095 \pm 45$ & $1460(95.4 \%) 1250 \mathrm{BC}$ \\
\hline
\end{tabular}

\section{CONCLUSION}

The growing amount of ${ }^{14} \mathrm{C}$ dates on cremated bone (CB) offers new insights into the chronological history of the urnfield cemeteries in northern France, Belgium, and the southern Netherlands. The present picture points to a complex and diversified scheme of regional and local evolutions in the funeral ritual. Some ideas about Late Bronze Age and Iron Age cultural-historical processes in the region will have to be modified.

The supposed chronology of the occupation phases of some cemeteries needs correction. It has been shown that some of these sites start earlier than previously thought, placing them already in, what is traditionally called, the Middle Bronze Age instead of the Late Bronze Age. The same phenomenon occurs at sites situated at the transition of the Early Iron Age to Late Iron Age.

The ${ }^{14} \mathrm{C}$ dates have shown that the internal chronology of the cremation sites is much more complex than previously thought. This has important consequences for the interpretation of the internal organization of the site. It now remains to determine whether burial sites should be chronologically relocated from one period to another or if the boundaries between the chronological phases should be adapted according to the new data.

\section{ACKNOWLEDGMENTS}

This research was sponsored by a FWO-Flanders project (nr. 1.5.029.07) for the dating of some of the Belgian sites. We would like to thank Luc Van Impe for his information about the ${ }^{14} \mathrm{C}$ dates from Neerharen-Rekem, and Guido Creemers for the use of the unpublished information of the excavation at Tessenderlo. Françoise Lafage was so kind as to send us information about the ${ }^{14} \mathrm{C}$ dates from Changis-sur-Marne. We wish to thank John Hammond for correcting the English text.

\section{REFERENCES}

Blanchet J-C, Talon M. 2005. L'âge du Bronze dans la moyenne vallée de l'Oise - apports récents. In: Bourgeois J, Talon M, editors. L'âge du Bronze du nord de la France dans son contexte européen. Paris: CTHS/ APRAB. p 227-68.

Bourgeois J. 1991. Enclos et nécropole de second âge du ferà Kemzeke (Stekene, Flandre orientale). Rapport provisoire des fouilles 1988. Scholae Archeologicae 12. Gent: Seminarie voor Archeologie RUG. 41 p.

Bourgeois J. 1999. De Metaaltijden in Vlaanderen. In: Art J, editor. Hoe schrijf ik de geschiedenis van mijn gemeente. Deel 4 archeologie. Gent: Centrum voor Geschiedenis/Stichting Mens en Kultuur. p 215-76.

Bourgeois J, Cherretté B. 2005. L'âge du Bronze et le premier âge du Fer dans les Flandres occidentale et orientale (Belgique): un état de la question. In: Bourgeois J, Talon M, editors. L'âge du Bronze du nord de la France dans son contexte européen. Paris: CTHS/ 
APRAB. p 43-81.

Bourgeois J, Verlaeckt K, Van Strydonck M. 1996. Belgian Bronze Age chronology: results and perspectives. In: Randsborg K. editor. Absolute Chronology. Archaeological Europe 2500-500 BC. Acta Archaeologica 67/Acta Archaeologica Supplementa I. København: Munksgaard International Publishers. p 41-152.

Bourgeois Q, Arnoldussen S. 2006. Expressing monumentality: some observations on the dating of Dutch Bronze Age barrows and houses. Lunula. Archaeologia Protohistorica 14:13-25.

Brindley AL. 2007. The Dating of Food Vessels and Urns in Ireland. Bronze Age Studies 7. Galway: Department of Archaeology, National University of Ireland. $392 \mathrm{p}$.

Brun P. 1984. La civilisation des Champs d'Urnes. Etude critique dans le Bassin parisien. Documents d'Archéologie Française 4. Paris. Editions MSHP. 168 p.

Brun P. 1988. L'entité Rhin-Suisse-France orientale; nature et évolution. In: Brun P, Mordant C, editors. $L e$ groupe Rhin-Suisse-France oriëntale et la notion de la civilisation des Champs d'Urnes. Mémoires du Musée de Prehistorie d'Ile-de-France 1. Nemours: APRA Ilede-France. p 591-8.

Cattelain P. 2002. Vestiges d'occupation du deuxième âge du Fer dans la grotte de la Roche Alberic à Couvin (Province de Namur, Belgique). In: Meniel P, Lambot $\mathrm{B}$, editors. Repas des vivants et nourriture pour les morts en Gaule. Actes du XXVe colloqie international de l'AFEAF Charleville-Mézières 24-27 mai 2001. Mémoire de la Société Archéologique Champenoise 16. Reims: Société Archéologique Champenoise. p 23-32.

Cottiaux R, Lawrence-Dubovac P, Durand S, Delattre V. 2001. Les occupations néolithiques et protohistoriques du site de Mareuil-les-Meaux «les Vignolles» (77), résultats préliminaires. In: Actualité archéologique régionale d'Ile-de-France. Actes des Journées Archéologiques d'Ile-de-France, 2001. Saint-Denis: Service régional d'archéologie d'Ile-de-France. p 60-3.

Creemers G. 1994. Noodonderzoek van een urnenveld te Tessenderlo-Engsbergen (Limb.). Lunula. Archaeologia Protohistorica 2:27.

Creemers G. 1997. Het urnenveld van Tessenderlo-Engsbergen (Lb.). Lunula. Archaeologia Protohistorica 5 : 13-4.

De Boe G, De Bie M, Van Impe L. 1992. Neerharen-Rekem. Die komplexe Besiedlungsgeschichte einer vor den Kiesbaggern geretteten Fundstatte. In: Spurensicherung. Archäologische Denkmalpflege in der Euregio Maas-Rhein. Mainz: Philipp von Zabern Verlag. p 477-96.

De Laet SJ, Marien ME. 1950. La nécropole de LommelKattenbosch. L'Antiquité Classique 19:309-66.

De Laet SJ, Thoen H, Bourgeois J. 1986. Les fouilles $d u$ Séminaire d'Archéologie de la Rijkuniversiteit te Gent à Destelbergen-Eenbeekeinde (1960-1984) et l'his- toire la plus ancienne de la région de Gent (Gand). I. La période préhistorique. Dissertationes Archaeologicae Gandenses 23. Brugge: De Tempel. 225 p.

Delaruelle St, De Smaele B, Van Doninck J. 2008. Ovalen voor de doden. Opgraving van een grafmonument uit de bronstijd aan de Mezenstraat in Beerse (provincie Antwerpen, België). Lunula. Archaeologia Protohistorica 16:31-8.

De Mulder G. 1994. Aspects of the funeral ritual in the Late Bronze Age and the Early Iron Age in the western part of the Flemish region. Helinium 34(1):94-133.

De Mulder G, Van Strydonck M. 2008. Een ${ }^{14} \mathrm{C}$-datering van het urnengrafveld te Kontich/Duffelsesteenweg (provincie Antwerpen, België). Lunula. Archaeologia Protohistorica 16:61-3.

De Mulder G, Van Strydonck M, Boudin M, Lerclercq W, Paridaens N, Warmenbol E. 2007. Re-evaluation of the Late Bronze Age and Early Iron Age chronology of the western Belgian urnfields based on ${ }^{14} \mathrm{C}$ dating. Radiocarbon 49(2):499-514.

De Mulder G, Lerclercq W, Van Strydonck M. 2008. Influence from the 'groupe Rhin-Suisse-France orientale' on the pottery from the Late Bronze Age urnfields in Western Belgium. A confrontation between pottery building technology, ${ }^{14} \mathrm{C}$ dates and typochronology. In: Berg I, editor. Breaking the Mould: Challenging the Past through Pottery. British Archaeological Reports. International Series 1861. Oxford: Archaeopress. p 105-15.

Desittere M. 1968. De Urnenveldenkultuur in het gebied tussen Neder-Rijn en Noordzee (Periodes Ha A en B). Dissertationes Archaeologicae Gandenses XI. Brugge: De Tempel. $158 \mathrm{p}$.

Gaudefroy St, Le Goff I. 2004. La nécropole du début du Bronze final de Verneuil-en-Hallate (Oise). Revue Archéologique de Picardie 1/2:19-32.

Gerritsen F. 2003. Local Identities. Landscape and Community in the Late Prehistoric Meuse-Demer-ScheldeRegion. Amsterdam Archaeological Studies 9. Amsterdam: Amsterdam University Press. 306 p.

Hessing W, Kooi P. 2005. Urnfields and cinerary barrows. Funerary and burial ritual in the Late Bronze and Iron Ages. In: Louwe Kooijmans LP, van den Broecke PW, Fokkens H, van Gijn AL, editors. The Prehistory of the Netherlands. Volume 2. Amsterdam: Amsterdam University Press. p 631-54.

Hissel M, Parlevliet M, Verspay J. 2007. Begraven, bewonen, beakkeren. Archeologisch onderzoek bij de uitbreiding van de woonwijk Genoenhuis, gemeente Geldrop-Mierlo (Noord-Brabant). AAC Publicaties 29. Amsterdam: Amsterdams Archeologisch Centrum. $325 \mathrm{p}$.

Kimmig W. 1988. Les champs d'urnes de l'Europe centrale. Remarques à propos du colloque de Nemours. In: Brun P, Mordant C, editors. Le groupe Rhin-Suisse-France oriëntale et la notion de la civilisation des Champs d'Urnes. Mémoires du Musée de Prehistorie 
d'Ile-de-France 1. Nemours: APRA Ile-de-France. p 11-5.

Kortlang F. 1999. The Iron Age urnfield and settlement of Someren-'Waterdael.' In: Theuws F, Roymans N, editors. Land and Ancestors. Cultural Dynamics in the Urnfield Period and the Middle Ages in the Southern Netherlands. Amsterdam Archaeological Studies 4. Amsterdam: Amsterdam University Press. p 133-97.

Lafage F, Auxiette G, Brunet P, Delattre V, Le Jeune Y, Martial E, Matterne V, Praud I. 2007. Changis-surMarne «les Pétreaux»: trois siècles d'évolution d'établissements ruraux de la fin du Bronze final au début du premier Âge du Fer. Bulletin de la Société Préhistorique Française 104(2):307-41.

Lanting JN, Brindley AL. 1998. Dating cremated bone: the dawn of a new era. Journal of Irish Archaeology 9: $1-7$.

Lanting JN, van der Plicht J. 2001/2002. De ${ }^{14}$ C-chronologie van de Nederlandse pre- en protohistorie IV: bronstijd en vroege ijzertijd. Palaeohistoria 43-44: $117-262$.

Lanting JN, van der Plicht J. 2005/2006. De ${ }^{14} \mathrm{C}$-chronologie van de Nederlandse pre- en protohistorie V: midden en late ijzertijd. Palaeohistoria 47-48:241-427.

Lanting JN, Aerts-Bijma AT, van der Plicht J. 2001. Dating of cremated bones. Radiocarbon 43(2A):249-54.

Le Guen P, Pinard E. 2007. La nécropole à incinération de Presles-et-Boves, «Les Bois Plantés» (Aisne): approche des pratiques funéraires du Bronze final dans la vallée de l'Aisne. In: Baray L, Brun P, Testart A, editors. Pratiques funéraires et sociétés. Nouvelles approches en archéologie et en anthropologie sociale. Dijon: Editions Universitaires de Dijon. p 101-14.

Nadeau MJ, Grootes PM, Schliecher M, Hasselberg P, Rieck A, Bitterling M. 1998. Sample throughput and data quality at the Leibniz-Labor AMS facility. Radiocarbon 40(1):239-45.

Naysmith P, Scott EM, Cook GT, Heinemeier J, van der Plicht J, Van Strydonck M, Bronk Ramsey C, Grootes PM, Freeman SPHT. 2007. A cremated bone intercomparison study. Radiocarbon 49(2):403-8.

Olsen J, Heinemeier J, Bennike P, Krause C, Hornstrup KM, Thrane H. 2008. Characterisation and blind testing of radiocarbon dating of cremated bone. Journal of Archaeological Science 35(3):791-800.

Peake R. 2007. Contextes funéraires et domestiques de l'Âge du Bronze à Marolles-sur-Seine (Seine-etMarne): un bilan de connaisances. In: Evin J, editor. Un siècle de construction du discours scientifique en Préhistoire. Volume III «...Aux conceptions d'aujourd'hui». Paris: Société préhistorique française. p 561-72.

Peake R, Delattre V. 2005. L'apport des analyses ${ }^{14} \mathrm{C}$ à l'étude de la nécropole de l'âge du Bronze de "La Croix de la Mission" à Marolles-sur-Seine. Revue Archéologique du Centre de la France 44:5-25.

Robertz A. 2008. La grotte de la "Roche Alberic" à Cou- vin (province de namur, Belgique; âge du Fer): contribution par l'étude du matériel céramique. Lunula. Archaeologia Protohistorica 16:107-16.

Roymans N, Kortlang F. 1999. Urnfield symbolism, ancestors and the land in the Lower Rhine region. In: Theuws F, Roymans N. editors. Land and Ancestors. Cultural Dynamics in the Urnfield Period and the Middle Ages in the Southern Netherlands. Amsterdam Archaeological Studies 4. Amsterdam: Amsterdam University Press. p 33-61.

Sheridan A. 2003. New dates for Scottish Bronze Age cinerary urns: results from the National Museums of Scotland dating cremated bones project. In: Gibson A. editor. Prehistoric Pottery. People, Pattern and Purpose. BAR International Series 1156/Prehistoric Ceramics Research Group: Occasional Publication no. 4. Oxford: Archaeopress. p 201-26.

Theunissen M. 1993. Het grafveld van Rijkevorsel/Hellehoekheide (A.) 700-400 BC. Lunula. Archaeologia Protohistorica 1:41-2.

Tol A. 2000. Opgravingen in het Hoogveld te Sittard. Campagne 1998. In: Tol A, Roymans N, Hiddink H, Kortlang F, editors. Twee urnenvelden in Limburg. Zuidnederlandse Archeologishe Rapporten 6. Amsterdam: Vossiuspers AUP. p 93-160.

Toron S. 2006. De la Picardie aux Flandres belges: une approche comparative des enclos circulaires de l'âge du Bronze ancien et moyen. Lunula. Archaeologia Protohistorica 14:71-6.

van den Broeke PW. 1987. De dateringsmiddelen voor de ijzertijd van Zuid-Nederland. In: van der Sanden WAB, van den Broeke PW, editors. Getekend zand. Tien jaar archeologisch onderzoek in Oss-Ussen. Bijdragen tot de Studie van het Brabantse Heem 31. Waalre: Stichting Brabants Heem. p 23-43.

van den Broeke PW. 2001. Een gordel van macht en pracht. Het Midden-Nederlandse rivierengebied in het $1^{\text {ste }}$ millennium v. Chr. In: Bourgeois J, Crombé Ph, De Mulder G, Rogge M, editors. Een duik in het verleden. Schelde, Maas en Rijn in de pre-en protohistorie. Publicaties van het Provinciaal Archeologisch Museum van Zuid-Oost-Vlaanderen — site Velzeke. Gewone reeks 4. Zottegem: Provinciaal Archeologisch Museum van Zuid-Oost-Vlaanderen-site Velzeke. p 131-56.

van den Broeke PW. 2008. Crematiegraven uit de vroege ijzertijd in Nijmegen-Lent. Archeologisch onderzoek aan de Steltsestraat. Archeologische Berichten Nijmegen-Rapport 8. Nijmegen: Bureau Archeologie en Monumenten. $36 \mathrm{p}$.

Van Impe L. 2001. Omtrent een voorgeschiedenis die men de Metaaltijden noemt. In: Bourgeois J, Crombé $\mathrm{Ph}$, De Mulder G, Rogge M, editors. Een duik in het verleden. Schelde, Maas en Rijn in de pre- en protohistorie. Publicaties van het Provinciaal Archeologisch Museum van Zuid-Oost-Vlaanderen-site Velzeke. Gewone reeks 4. Zottegem: Provinciaal Ar- 
cheologisch Museum van Zuid-Oost-Vlaanderensite Velzeke. p 87-93.

Van Strydonck M, Boudin M, Hoefkens M, De Mulder G. 2005. ${ }^{14} \mathrm{C}$-dating of cremated bones, why does it work? Lunula. Archaeologia Protohistorica 13:61-3.

Van Strydonck M, Boudin M, De Mulder G. 2009. ${ }^{14} \mathrm{C}$ dating of cremated bones: the issue of sample contamination. Radiocarbon, this issue.
Van Strydonck M, van der Borg K. 1990/1991. The construction of a preparation line for AMS-targets at the Royal Institute for Cultural Heritage Brussels. Bulletin Koninklijk Instituut voor het Kunstpatrimonium 23:228-34.

Verwers GJ. 1972. Das Kamps Veld in Neolithikum, bronzezeit und Eisenzeit. Analecta Praehistorica Leidensia V. Leiden: Leiden University Press. 176 p. 